\title{
Religion, theology and cosmology
}

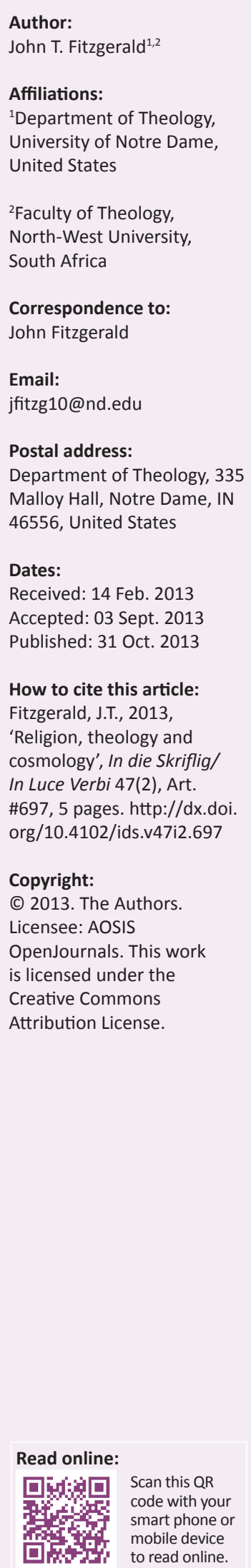

Cosmology is one of the predominant research areas of the contemporary world. Advances in modern cosmology have prompted renewed interest in the intersections between religion, theology and cosmology. This article, which is intended as a brief introduction to the series of studies on theological cosmology in this journal, identifies three general areas of theological interest stemming from the modern scientific study of cosmology: contemporary theology and ethics; cosmology and world religions; and ancient cosmologies. These intersections raise important questions about the relationship of religion and cosmology, which has recently been addressed by William Scott Green and is the focus of the final portion of the article.

Godsdiens, teologie, en kosmologie. Kosmologie is tans een van die belangrikste navorsingsterreine en ontwikkelings in moderne kosmologie. Dit het ' $n$ nuwe belangstelling wakker gemaak in die verband wat tussen godsdiens, teologie en kosmologie bestaan. Hierdie artikel, wat bedoel is as ' $n$ bondige inleiding tot die artikelreeks oor die teologiese kosmologie in hierdie tydskrif, identifiseer drie algemene areas wat van teologiese belang is: die hedendaagse teologie en etiek; die kosmologie en wêreldgodsdienste; en die antieke kosmologieë. Die verband wat tussen hierdie velde bestaan, opper belangrike vrae oor die verhouding tussen godsdiens en kosmologie wat onlangs deur William Scott Green behandel is. Dit is die fokus van die laaste deel van die artikel.

\section{Introduction ${ }^{1}$}

It is often said that we are living today in 'the golden age of cosmology'. To cite just one example of such a claim, the first chapter in a 2011 publication dealing with galaxies and the endeavour to find the best cosmological model to describe their size, age, geometry and material composition is titled 'The golden age of cosmological physics' (Baryshev \& Teerikorpi 2011). Such language is fully understandable, given advances in astrophysics, particle physics and string theory and the enhancement of the various means and methods of conducting research into the macrocosmic and microcosmic realms of the universe, including computer modelling, radio-telescopes and particle accelerators (Wright 1995:1). As in antiquity, also in the contemporary world the investigation into cosmology - the state of the universe - also entails an examination of cosmogony - the origins of the universe.

\section{Modern cosmogonies}

It is perhaps telling that the centre of attention in the popular realm has been cosmogony or, to be more precise, a particular cosmogonic theory, the so-called 'big bang theory' which was originally proposed by a Belgian priest by the name of Georges LeMaître from the Catholic University of Leuven. The theory, which grew out of LeMaître's earlier work on the idea of an expanding universe (1927) and quantum theory (1931), was known as 'the hypothesis of the primeval atom' (LeMaître 1946; see also Berger 1984). It was refined, publicised and popularised by George Gamow (1961), one of the Manhattan Project scientists, who compared it to the explosion of the atomic bombs that ended World War II when they were dropped by the US military on the Japanese cities of Hiroshima and Nagasaki. The term by which the developing theory became known, namely the big bang, was, however, coined in 1949 by one of its opponents, Sir Fred Hoyle, a physicist who argued on behalf of the so-called 'steady-state' theory, later modified to a quasi-steady-state theory (Hoyle, Burbidge \& Narlikar 2000). The big-bang theory presupposes that the universe is

The following article is intended as a general introduction to the studies on cosmology that are being published in this journal. The articles in this series focus on various cosmologies of the ancient world, especially those found in Jewish and Christian authors, yet they are prompted not only by a resurgence of interest in biblical and other ancient cosmologies, but also by the general contemporary interest in cosmology, especially as it relates to both theology and the academic study of religion. The purpose of this introductory article is briefly to indicate two other areas of current theological interest in cosmology and to summarise the reflections of one leading contemporary theorist of religion on the importance of cosmology for the study and understanding of religion. It is the hope of all contributors to this series that our treatments of ancient cosmology will prompt studies of cosmology by scholars who work in different disciplines. 
in a constant state of change and is always evolving. It has, however, a beginning in time and space, and that beginning occurred when there was a huge explosion some 12 to 15 billion years ago. The steady-state theory, by contrast, has no initial cosmic fireworks, but rather presupposes an eternal universe that has neither beginning nor end and does not change its appearance over time, because new matter is continuously generated as the universe expands. There are at most 'mini explosions' in this accelerating universe, but no initial 'big bang' (Narlikar, Vishwakarma \& Burbidge 2002). Although modern debates about these two rival theories are far from over, it is clear that the big-bang theory enjoys much greater scientific support than the quasi steady-state theory, with one reviewer calling the latter hypothesis 'far off the main road' of contemporary scientific thinking (Kundt 2001:611). Such debates, however, are not new. Similar debates between advocates of an eternal universe and proponents of a universe with a temporal beginning occurred in antiquity with some defending creationism and others attacking it (Sedley 2007). Therefore, this has been a long conversation about the enigma of the origins of the universe.

\section{Cosmology and theology}

In the light of the widespread interest in modern cosmology and attempts to compare and contrast it to ancient cosmologies, especially the cosmology found in Plato's Timaeus (Brisson \& Meyerstein 1995), it is not surprising that biblical scholars, ethicists and theologians have also been prompted to address the issue of cosmology with at least three different areas receiving attention. Some scholars focus on modern cosmology and the various issues that it poses for theology and ethics. Others examine the role cosmology plays in the different world religions; and there are also those who investigate biblical and other ancient cosmologies such as that of Stoicism, where there was an intimate connection between theology and cosmology (Salles 2009).

\section{Modern cosmology and theology}

Examples of the first area of study are two volumes by Rodney Holder, who is interested in demonstrating that modern cosmology supports an argument for the existence of God from design and wishes, on that basis, to reclaim natural theology as a viable theological endeavour (Holder 2004). As is well-known, the attempt to find evidence for the existence of God in the structured order of the world was not highly esteemed by the great Swiss theologian Karl Barth. Holder (2012) seeks to demonstrate both the legitimacy of natural theology and the persuasiveness of a new argument for design based on the evidence of modern cosmology.

However, contemporary theological interest in cosmology is not restricted to a concern with the existence of God. For instance, Robert John Russell's recent study of Wolfhart Pannenberg, a theologian well-known for his contributions to the modern dialogue between the natural sciences and systematic theology, examines the connection between cosmology and eschatology within the context of Pannenberg's Trinitarian conception of time and omnipresence and in light of modern mathematics, physics and scientific cosmology (Russell 2012; see also Lebkücher 2011). Similarly, based on the pioneering work of Pierre Teilhard de Chardin (1881-1955), Alex Garcia-Rivera (2009) calls for the construction of a new theological cosmology. As these examples suggest, there is a strong and growing interest in the intersections of theology and cosmology.

\section{Modern cosmology and world religions}

An example of the second field of study, namely, cosmology in world religions, is seen in the recent volume by Nicholas Campion (2012) on Astrology and cosmology in the world's religions. This endeavour is grounded in an observation made a century ago by Émile Durkheim (2001:10), who cogently remarked: 'There is no religion that is not a cosmology as well as a speculation on the divine.' Using that insight by Durkheim, Campion surveys the ways in which astrology functions within the cosmological beliefs of the religions of the world. This is a valuable endeavour, especially since astrology has quite often been linked with cosmology in the history of discourse about the cosmos (e.g. Ruggles 2005). Campion's own academic strength is astrology, not religion, but he is surely correct in saying that cosmology 'deals with the ways in which human beings locate themselves in relation to the cosmos, seen as the totality of everything' (Campion 2012:10).

\section{Cosmology and antiquity}

The third area of current research on cosmology deals with the cosmologies of the ancient world in general (e.g. Fitzgerald 2013); with cosmologies in the ancient Near East (Walton 2011) and in the Greek world (Couprie 2011); with cosmology and art (Laderman 2013); with the cosmologies of specific authors such as Aeschylus (Seaford 2012), Aristotle (Kouremenos 2010), Philo (Anderson 2011) and Plato (Schmidt 2012); and with early Christian cosmology in particular. Interest in this last area is strong and growing (Boustan \& Reed 2004; Engberg-Pedersen 2010; Köckert 2009; Lewis 2013; Lyman 1993; Nicklas, Pennington \& McDonough 2008; Ryan 2012; Siniossoglou 2008; Stephens 2011; Thomson 2012; Zamfir \& Braun 2010) and is the focus of the articles published in this series of the journal In die Skriflig/In Luce Verbi. It is important to remember, however, that these studies are not taking place in a theological vacuum, but belong to the current broader inquiry regarding God, religion and cosmology. Indeed, all three of the areas I have mentioned, that is, contemporary theology and ethics, world religions and ancient cosmology, including biblical cosmogonies and cosmologies, are sometimes addressed collectively and the results published together. The best-known volume of this kind is one that emerged from a series of conferences held at the University of Chicago in 1981 and 1982 and which was published with the title Cosmogony and ethical order: New studies in comparative ethics (Lovin \& Reynolds 1985). Our aim with the articles published in In die Skriflig/In Luce Verbi is more focused, but the results have implications also for these other areas of study. 


\section{Religion and the cosmos}

The great importance of cosmology for theology, especially Christian theology, raises the more fundamental issue of the general relationship of religion to the cosmos. This relationship has not received as much recent attention as it merits. Therefore, I shall devote the final section of this introduction to a brief discussion of this relationship as viewed from the perspective of religion. Instead of providing a survey of all the various points of view (both religious and non-religious) on this topic, it will be more fruitful to focus here on the important work of William Scott Green, who has given attention to this matter in a recent article (Green 2010). His views, of course, are not the only ones on this subject - and it is emphatically not the views of most modern cosmologists, who typically are atheists (Carroll 2005) - but I personally view them as particularly useful and suggestive, especially for biblical scholars who focus on the ancient world and seldom work on general theories of religion. ${ }^{2}$

Green accepts as a working definition of religion the formulation of the anthropologist Melford Spiro, who defines religion as 'an institution consisting of culturally patterned interaction with culturally postulated superhuman beings' (Spiro 1987:197). One of Green's foci is this interaction of humans with superhuman beings within the context of a cosmos that is both normative and humanly relevant. He (Green 2010) begins by affirming that:

Judaism, Christianity, Islam, Hinduism, and Buddhism all aver that there is an order to existence - a reality, a set of life conditions and circumstances - that humans did not make and in principle cannot change. Superhuman beings normally play a role in bringing this order about or in discerning it, or both. This cosmic order constitutes the foundation and framework for human action in the world. (p. xiii)

After citing the opening verses of Genesis and the Gospel of John plus texts from the Qu'ran and a Vedic hymn, Green (2010) continues by making the following observation:

These texts nowhere suggest that humans played any role in shaping the structure of reality. Human beings did not produce themselves; nor did they create light and darkness, time and space, day and night, or Brahmins and serfs. Humans did not vote these conditions into being, and they cannot vote them out of existence. Rather, the cosmos establishes the givens of existence and constitutes the prerequisites of human experience.

In religion, this cosmic structure is neither speculation nor conjecture nor provisional hypothesis. To the contrary, it is objective, factual, and true. More important, it is normative. It depicts not only how things are, but how things should be. Religion claims not only to account for this world as it is but also to perceive a structure beneath or beyond it. For instance, although the cosmos contains an array of animals and plants that humans can consume, some religions - Judaism, Hinduism, and Jainism, for example - prohibit the consumption of certain animals or plants on the grounds that eating them requires taking

2.William Scott Green is a scholar of Rabbinic Judaism and theorist of religion who spent a decade serving as editor of the Journal of the American Academy of Religion. spent a decade serving as editor of the Journal of the American Academy of Religion. Green and I were colleagues for six years at the University of Miami and co-taugh the Department of Religious Studies' course on theories of religion. My conversation with Green on the academic study of religion and co-teaching that seminar profoundly influenced my understanding of religion and of the relationship between religion and cosmology, and my extensive use of his most recent article on this topic is but a small reflection of my indebtedness to him. life or otherwise violates a deep cosmic structure. Religion's claim to know the normative structure of the cosmos shapes the character of religious behavior or at least the religious view of human behavior. (pp. xiv-xv)

This emphasis on religion's claim to knowledge about the cosmos sets it apart from all philosophical speculation, especially from the theories of the Pre-Socratic Greek philosophers in Ionia, Italy and Sicily who sought to identify the basic substance or principle underlying all things in the universe, that is, 'the ultimate foundational reality of the cosmos' (Curd 2011:4). The first three Milesians each suggested something different as the foundational reality of the cosmos, with Thales arguing for water, Anaximander for the boundless or indefinite and Anaximenes for air. Later PreSocratic philosophers offered still other theories along with the supporting evidence for each hypothesis. Over against this theorising, religion claims to offer knowledge. In reality, of course, religion's cosmology may be purely speculative, devoid of any objective proof. It may be totally wrong, but what is important here is its claim to know. Furthermore, because it knows the fundamental structure of the universe, it also knows how to bring human behaviour into conformity with that cosmic structure. As Green (2010) puts it:

Religion operates on the assumption that humans on their own are, can be, or will be out of sync with the normative cosmic order and the superhuman beings who created, discovered, and understand it. Humans' incongruity with the cosmic order is the result either of humanity's willful intent, inherent weakness, human ignorance, or some combination of the three. Religion further claims to know how to correct and prevent this inconsonance. Religion expects human behavior - which includes attitudes as well as actions - to take the form of adherence, loyalty, fealty, devotion, or commitment to the cosmic order and conformity to its contours. It further supposes that there are serious negative consequences to humans' failure to do this and that only the religion can both explain these consequences and relieve them. Religions teach their adherents how the world should work, why it should work that way, what humans should do to live in accord with that normative structure, and what will happen to them if they do or do not do so. (p. xv)

Green (2010:xv) goes on to argue that this 'knowledge of the normative nature and structure of the cosmic order is particular rather than generic'. That means it is not knowledge that is generally available in all religions so that it can be acquired through any or all of them, but it is also not knowledge that can be autonomously acquired separate and apart from the religion that transmits this knowledge. Green (2010) argues:

Discrete religions typically do not claim that people can randomly, accidentally, or independently acquire what the religion knows about how the universe works and how humans are to act in it. (p. xv)

This is because 'full and correct knowledge and understanding' of cosmic order are ultimately dependent on the superhuman being (or beings) who 'created, discovered, or revealed that order', and thus this knowledge is regarded as specific or even exclusive to particular religions (Green 2010:xv). Therefore, despite their similar claims to knowledge and certain common features in their teachings about the cosmos, the cosmologies of the various religions are not interchangeable. 
Furthermore, Green (2010) notes:

Each religion has its own particular sources of authority texts, canons of scripture, revelations, sages, enlightened ones, prophets, chains of tradition, and so on - that reveal, transmit, and certify its privileged knowledge of the cosmic order. (p. xvi)

In short, religion qua religion tends to have a totalitarian and exclusivist bent when it comes to the privileged cosmic knowledge that it possesses and purveys. Specific religions may have great respect for other religions and their claims, but they generally do not view the cosmic knowledge that they impart to be identical with that of another religion or to lead to another religion. On the contrary, as Green (2010) points out:

... religion assumes that only by adhering to the religion's own teachings, which entail proper interactions with its superhuman beings, can humans either repair a breach with the cosmic order or prevent one from happening. (p. xvi)

As Green's astute comments suggest, scientific study of the cosmos may well lead the investigator to discern structures within the cosmos and to infer that some superhuman being has bestowed order on the cosmos, but it will not tell one how to live properly in conformity with that cosmic structure or reveal whether that order will change in the future. That is, such study will not reveal whether the cosmos will continue indefinitely or eternally as is, whether it will be destroyed at some future point in time and thus has an eschaton, or whether it will be changed and renewed. Nor can it reveal the purpose and goal, the telos of the cosmos. In short, neither scientific cosmology nor natural theology can reveal the privileged knowledge that religions, especially religions that appeal to revelation, claim to provide in terms of the identity and nature of the superhuman being who created, discovered or revealed the cosmos, the behavioural and ethical implications of cosmic structure and cosmic teleology and eschatology the meaning, aim and future of the cosmos. Such knowledge comes only in and through religion and that is why every major world religion has a cosmology.

In the Christian tradition, the biblical cosmogonies and cosmologies have particular importance, because they are foundational theological texts on which the tradition draws to understand God, the cosmos and the place of humans within cosmic structure. At the same time, these foundational texts were produced in a daunting variety of different times and circumstances. Furthermore, since they were not the first or the only cosmologies to be produced in the ancient Mediterranean world, it is important to study the biblical texts, not only in their own right, but also in relationship to other ancient cosmologies. The studies that comprise this series are collectively designed to provide both kinds of analysis.

\section{Acknowledgements Competing interests}

The author declares that he has no financial or personal relationship(s) which may have inappropriately influenced him in writing this article.

\section{References}

Anderson, C.A., 2011, Philo of Alexandria's views of the physical world, Mohr Siebeck, Tübingen.

Baryshev, Y. \& Teerikorpi, P., 2011, Fundamental questions of practical cosmology: Exploring the realm of galaxies, Springer, Dordrecht.

Berger, A. (ed.), 1984, The big bang and Georges LeMaître: Proceedings of a symposium in honour of Georges LeMaitre fifty years after his initiation of big-bang cosmology, Reidel, Boston. http://dx.doi.org/10.1007/978-94-009-6487-7

Boustan, R.S. \& Reed, A.Y. (eds.), 2004, Heavenly realms and earthy realities in late antique religions, Cambridge University Press, Cambridge. http://dx.doi.org/10.1017/ CBO9780511497889

Brisson, L. \& Meyerstein, F.W., 1995, Inventing the universe: Plato's Timaeus, the big bang, and the problem of scientific knowledge, State University of New York Press, Albany.

Campion, N., 2012, Astrology and cosmology in the world's religions, New York University Press, New York.

Carroll, S.M., 2005, 'Why (almost all) cosmologists are atheists', Faith and Philosophy 22(5), 622-635. http://dx.doi.org/10.5840/faithphil200522523

Couprie, D.L., 2011, Heaven and earth in ancient Greek cosmology: From Thales to Heraclides Ponticus, Springer, New York. http://dx.doi.org/10.1007/978-1-44198116-5

Curd, P. (ed.), 2011, A presocratics reader: Selected fragments and testimonia, 2nd edn., Hackett, Indianapolis.

Durkheim, É., 2001, The elementary forms of religious life, transl. C. Cosman, Oxford University Press, New York.

Engberg-Pedersen, T., 2010, Cosmology and self in the Apostle Paul: The material spirit, Oxford University Press, Oxford. http://dx.doi.org/10.1093/acprof:oso/ 9780199558568.001.0001

Fitzgerald, J.T., 2013, 'Cosmologies of the ancient Mediterranean world', In die Skriflig/ In Luce Verbi 47(2), Art. \#696, 7 pages. http://dx.doi.org/10.4102/idsv4712.696.

Garcia-Rivera, A., 2009, The garden of God: A theological cosmology, Fortress, Minneapolis. Gamow, G., 1961, The creation of the universe, rev. edn., Viking, New York.

Green, W.S., 2010, 'A "humanly relevant" cosmos: What we study when we study religion', in J. Neusner (ed.), Introduction to world religions, pp. vii-xxiii, Abingdon Nashville.

Holder, R.D., 2004, God, the multiverse, and everything: Modern cosmology and the argument from design, Ashgate, Aldershot, England.

Holder, R., 2012, The heavens declare: Natural theology and the legacy of Karl Barth Templeton, West Conshohocken, Pennsylvania.

Hoyle, F., Burbidge, G.R. \& Narlikar, J.V., 2000, A different approach to cosmology: From a static universe through the big bang towards reality, Cambridge University Press, Cambridge.

Köckert, C., 2009, Christliche kosmologie und kaiserzeitliche philosophie: Die auslegung des Schöpfungsberichtes bei Origenes, Basilius und Gregor von Nyssa vor dem hintergrund kaiserzeitlicher Timaeus-interpretationen, Mohr Siebeck, Tübingen.

Kouremenos, T., 2010, Heavenly stuff: The constitution of the celestial objects and the theory of homocentric spheres in Aristotle's cosmology, Steiner, Stuttgart. PMCid:PMC2991904

Kundt, W. 2001, 'Review of F. Hoyle, G. Burbidge \& J.V. Narlikar: A Different approach to cosmology', General Relativity and Gravitation 33(3), 611-614. http://dx.doi. org/10.1023/A:1010209210920

Laderman, S., 2013, Images of cosmology in Jewish and Byzantine art: God's blueprint of creation, Brill, Boston. http://dx.doi.org/10.1163/9789004252196, PMCid:PMC3619310

Lebkücher, A., 2011, Theologie der natur: Wolfhart Pannenbergs beitrag zum dialog zwischen theologie und naturwissenschaft, Neukirchener Theologie, NeukirchenVluyn.

LeMaître, G., 1927, 'Un Univers homogène de masse constante et de rayon croissant, rendant compte de la vitesse radiale des nébuleuses extra-galactiques' ['A homogeneous universe of constant mass and growing radius, accounting for the radial velocity of extragalatic nebulae'], Annales de la Société scientifique de Bruxelles 47, 49-59.

LeMaitre, G., 1931, 'The beginning of the world from the point of view of quantum theory', Nature 127(3210), 706. http://dx.doi.org/10.1038/127706b0

LeMaître, G., 1946, L'hypothèse de l'atome primitive: Essai de cosmogonie [The primeval atom hypothesis: An essay on cosmogony], Éditions du griffon, Neuchâtel.

Lewis, N.D., 2013, Cosmology and fate in Gnosticism and Graeco-Roman antiquity: Under pitiless skies, Brill, Leiden. http://dx.doi.org/10.1163/9789004245761

Lovin, R.W. \& Reynolds, F.E. (eds.), 1985, Cosmogony and ethical order: New studies in comparative ethics, University of Chicago Press, Chicago.

Lyman, J.R., 1993, Christology and cosmology: Models of divine activity in Origen, Eusebius and Athanasius, Clarendon, Oxford. http://dx.doi.org/10.1093/acprof:o so/9780198267454.001.0001

Narlikar, J.V., Vishwakarma, R.G. \& Burbidge, G., 2002, 'Interpretations of the accelerating universe', Publications of the Astronomical Society of the Pacific, 114(800), 1092-1096. http://dx.doi.org/10.1086/342374

Nicklas, T., Pennington, J.T. \& McDonough, S.M. (eds.), 2008, Cosmology and New Testament theology, T \& T Clark, London. 
Russell, R.J., 2012, Time in eternity: Pannenberg, physics, and eschatology in creative mutual interaction, University of Notre Dame Press, Notre Dame.

Ruggles, C.L.N., 2005, Ancient astronomy: An encyclopedia of cosmologies and myth, ABC-CLIO, Santa Barbara.

Ryan, M.R., 2012, Hearing at the boundaries of vision: Education informing cosmology in Revelation 9, T \& T Clark, London.

Salles, R. (ed.), 2009, God and cosmos in Stoicism, Oxford University Press, Oxford. http://dx.doi.org/10.1093/acprof:oso/9780199556144.001.0001

Schmidt, E.A., 2012, Platons zeittheorie: Kosmos, seele, zahl und ewigkeit im 'Timaios', Klostermann, Frankfurt am Main.

Seaford, R., 2012, Cosmology and the polis: The social construction of space and time in the tragedies of Aeschylus, Cambridge University Press, Cambridge.

Sedley, D.N., 2007, Creationism and its critics in antiquity, University of California Press, Berkeley.
Siniossoglou, N., 2008, Plato and Theodoret: The Christian appropriation of Platonic philosophy and the Hellenic intellectual resistance, Cambridge University Press, Cambridge.

Spiro, M.E., 1987, 'Religion: Problems of definition and explanation', in B. Kilborne \& L.L. Langness (eds.), Culture and human nature: Theoretical papers of Melford E. Spiro, pp. 187-222, University of Chicago Press, Chicago.

Stephens, M.B., 2011, Annihilation or renewal? The meaning and function of new creation in the book of Revelation, Mohr Siebeck, Tübingen.

Thomson, R.W. (ed.), 2012, Saint Basil of Caesarea and Armenian cosmology: A study of the Armenian version of Saint Basil's Hexaemeron and its influence on medieval of the Armenian version of Saint Basil's Hexaemeron

Walton, J.H., 2011, Genesis 1 as ancient cosmology, Eisenbrauns, Winona Lake.

Wright, M.R., 1995, Cosmology in antiquity, Routledge, London.

Zamfir, K. \& Braun, H. (eds.), 2010, Theologies of creation in early Judaism and ancient Christianity in honour of Hans Klein, De Gruyter, Berlin. PMCid:PMC2947995 